\section{Relief of Hypoglycæmic Convulsions with Butyric Acid}

TrE lower volatile acids, acetic, propionic and butyric, have been widely studied in relation to intermediary metabolism ${ }^{1,2}$. Propionic acid is known to be glucogenic, and sodium propionate has been found to relieve severe hypoglycæmic symptoms in an adrenalectomized ewe; but sodium acetate was without effect ${ }^{3}$. Butyric acid has usually been studied in relation to the metabolism of fat and the production of ketone bodies ${ }^{4}$; but there are some suggestions that it may also be implicated in carbohydrate metabolism ${ }^{5}$. Moreover, Jarrett, Potter and Filsell ${ }^{6}$ have found that the concentration of blood sugar and of pyruvic acid was increased after sodium butyrate had been injected into the blood-stream of sheep.

In view of the possible association of the metabolism of butyric acid with that of carbohydrate, the effect of sodium butyrate administration on an animal in convulsions was studied.

Eight young merino lambs aged between 1 and 28 days were fasted for $24 \mathrm{hr}$. and then given an intravenous injection of insulin in the manner employed by Comline et al. . The subsequent hypoglycæmic convulsions were found to be relieved by an intrajugular injection of $10 \mathrm{ml}$. sodium butyrate, containing $2.5 \mathrm{mM}$ butyric acid/ $\mathrm{kgm}$. neutralized to $p \mathrm{H} 7 \cdot 0$ with sodium hydroxide. Sodium propionate $(2.5 \mathrm{~m} M$ propionic acid $/ \mathrm{kgm}$. $)$ had a similar effect, but there was no response to sodium acetate $(2.5 \mathrm{mM}$ acetic acid $/ \mathrm{kgm}$.).

Convulsions which supervened in two adult ewes in which the splanchnic nerves had been sectioned ${ }^{8}$ were similariy relieved by $30 \mathrm{ml}$. of either butyrate or propionate but not by acetate.

Insulin-induced hypoglycæmic convulsions in rabbits were also relieved by $5 \mathrm{ml}$. of intravenous sodium butyrate $(2.5 \mathrm{mM}$ butyric acid/kgm.) and by propionate but not by acetate.

Total reducing sugar in the blood estimated in samples taken prior to the insulin injection, during convulsion, and ten minutes after the injection of the volatile acids, showed that the relief of the convulsions was accompanied by a considerable rise in blood sugar.

Convulsions in lambs ceased immediately after the injection of butyrate : the coma which supervened for 1-2 min. gradually subsided and within 5-10 min. the animals had regained their feet. An apparently normal state was maintained for about 30-40 min. : the animals then became lethargic and after 50-60 min. again convulsed. This second convulsion could be relieved with butyrate and if, on recovery, the animals were allowed to suck from their dams no further convulsions ensued.

Butyrate, when administered to the adult ewes, however, relieved hypoglycæmic convulsions but with less spectacular effect. Acetate was found to be ineffective and propionate gave no more relief than butyrate.

Rabbits were observed to respond to butyrate injection in much the same manner as lambs and ewes. On some occasions the coma that followed the injection persisted for as long as $20 \mathrm{~min}$., after which the animals recovered rapidly and began to eat if allowed access to food. If prevented from feeding, they became convulsed again 60-90 min. later, and under these conditions were relieved by another injection of butyrate. Acetate was again ineffective

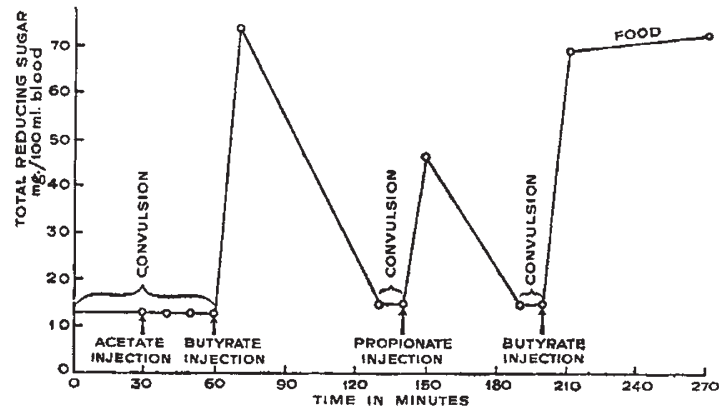

Blood sugar curves of lamb $F$ (aged 28 days) after sodium acetate, propionate or butyrate $(2 \cdot 5 \mathrm{mM} / \mathrm{kgm}$.)

and propionate did not relieve the symptoms as effectively in the rabbits as in the lambs and sheep.

The concentration of sugar in the bloods of the lambs was raised from the low level of $10-15 \mathrm{mgm} . / 100$ ml. to which it fell during the convulsions, to $50-80$ $\mathrm{mgm} .100 \mathrm{ml}$. ten minutes after the injection of butyrate. Injection of propionate led to a rise of only $30-40 \mathrm{mgm} . / 100 \mathrm{ml}$., while acetate produced no alteration in the blood-sugar level (see graph).

Similar results were obtained with adult sheep and rabbits : the butyrate in all cases led to a greater increase in blood sugar than the propionate. The sugar in the blood of rabbits, however, was not increased as much as that of the lambs and sheep, but it remained elevated for a longer period.

Sodium propionate is known to be glucogenic and therefore might be expected to relieve hypoglycæmic convulsions : the greater efficiency with which sodium butyrate can also relieve them suggests that butyric acid may readily be converted to glucose in vivo. The mechanism of this conversion is obscure.

\section{B. J. PotTer}

Division of Biochemistry and General Nutrition,

Commonwealth Scientific and

Industrial Research Organization, University of Adelaide. Feb. 27.

${ }^{1}$ Marston, H. R., Biochem. J., 42, 564 (1948).

${ }^{2}$ Phillipson, A. T., "Ann. Rev. Biochem.", 17, 705 (1948).

${ }^{3}$ Reid, R. L., Aust. J. Agric. Res., 2, 146 (1951).

"Stadie, W. C., "Ann. Rev. Biochem.", 15, 219 (1946).

${ }^{5}$ Blixenkrone-Moeller, N., Z physiol. Chsm., 252, 137 (1938). Buchanan, J. M., Hastings, A. B, and Nesbett, F. B., J. Biol. Chem. 150, 413 (1943).

- Jarrett, I. G., Potter, B. J., and Filsell, O. H., Aust. J. Exp, Biol. Med. Sci. (in the press).

${ }^{7}$ Comline, R. S., Titchen, D. A., and Jarrett, I. G. (in preparation).

${ }^{8}$ Comline, R. S., Titchen, D. A., Jarrett, I. G., and Potter, B. J. (in preparation).

- Shaffer, P. A,. and Somogyi, M., J. Biol. Chem., 100, 695 (1933).

\section{'Lipochondria' and the Golgi Substance in Epithelial Cells of the Epididymis}

Вотн J. R. Baker ${ }^{1}$ and O. L. Thomas ${ }^{2}$ have expressed the view that 'lipochondria' (discrete sudanophilic droplets supravitally stainable with methylene blue and neutral red) are transformed into the classical Golgi network during the processes of fixation and impregnation with silver and osmic acid techniques. Thomas ${ }^{3}$ also considers that mitochondria are involved in the develop- 